\title{
The State of Law in Vietnam: Understandings, Prospects and Challenges
}

\author{
Vu Cong Giao
}

\section{The Concept of the State of Law}

The idea of the state of law emerged long ago in human history. As early as in antiquity, philosophers like Socrates (469-399 B.C.), Aristotle (384-322 B.C.), and Cicero (106-43 B.C.) described the characteristics of a state ruled by law. For instance, in Plato's Crito Socrates expresses that an individual must always adhere to the state and state law. ${ }^{1}$ Aristotle also affirms: "A state is stable only when men are equal to law," meanwhile Cicero believes that: "we are in bondage to the law in order that we may be free". ${ }^{3}$ Those ideas are reinforced by European and American thinkers such as St. Thomas Aquinas (12251274), John Locke (1632-1704), Charles de Montesquieu (1698-1755), Jean-Jacques Rousseau (1712-1778), Immanuel Kant (1724-1804), Thomas Jefferson (1743-1826), Thomas Paine (1737-1809), John Adams (17351826), Georg Wilhelm Friedrich Hegel (1770-1831) then becoming a legal theory, particularly in the period of Enlightenment. The idea of the rule of law was also regulated in a number of legal documents in some countries in medieval times. For example, the well-known Great Charter Magna Carta (1285) of England stipulated that:

\footnotetext{
${ }^{1}$ Stephens (1985), 3-10.

${ }^{2}$ www.quotationspage.com/quote/28897.htm.

${ }^{3}$ quotes.liberty-tree.ca/quote_blog/Marcus.Tullius.Cicero.Quote.7330.
} 
"No free man shall be seized or imprisoned, or stripped of his rights or possessions, or outlawed or exiled, or deprived of his standing in any way, nor will we proceed with force against him, or send others to do so, except by the lawful judgment of his equals or by the law of the land."

As time went on, many definitions of the state of law have been proposed each of which defined some certain properties of the rule of law. For instance, Anthony Kennedy, Chief Justice of the United States, has said:

"When we talk about the rule of law, we assume that we are talking about a law that promotes freedom, that promotes justice, that promotes equality. ${ }^{5}$

The Oxford dictionary provides a shorter definition of the rule of law:

"The restriction of the arbitrary exercise of power by subordinating it to well-defined and established laws. "

Besides, there have been some more detailed definitions, for example, according to the World Justice Project (WJP):

"State of law is a framework of rights and rules that created the foundation of social justice and prosperity. This is a system in which no entity, including the government, can stand above the law; where laws protect fundamental rights; and where everyone has rights to access to justice."

According to the Secretary General of the United Nations:

"The rule of law refers to a principle of governance in which all persons, institutions and entities, public and private, including the state itself, are accountable to laws that are publicly promulgated, equally enforced and independently adjudicated, and which are consistent with international human rights norms and standards. It requires, as well, measures to ensure adherence to the principles of supremacy of law, equality before the law, accountability to the law, fairness in the application of the law, separa-

${ }^{4}$ Magna Carta, article 39, at: http://www.historylearningsite.co.uk/magna_carta-transcript.htm.

${ }^{5}$ See also: ABA, What is rule of law, http://www.americanbar.org/content/dam/aba /migrated/publiced/features/Part1DialogueROL.authcheckdam.pdf.

6 http://www.oxforddictionaries.com/definition/english/rule\%2Bof\%2Blaw $1 ? \mathrm{q}=-$ rule + of +law.

${ }^{7}$ http://worldjusticeproject.org/what-rule-law. 
tion of powers, participation in decision-making, legal certainty, avoidance of arbitrariness and procedural and legal transparency. "s

Although the content and the way of expression are somewhat different, however, to some extent, those above-mentioned definitions of the rule of law focus on the relationships between people and government. This is the core relationship and the foundation of every society derived from nature and the demands of existence of human society. The nature of this relationship, as succinctly summed up by James Madison - one of the founders of the U.S. Constitution:

"If men were angels, no government would be necessary. In framing a government which is to be administered by men over men, the great difficulty lies in this: You must first enable the government to control the governed; and in the next place, oblige it to control itself."

Nevertheless, it is necessary to confirm that the state of law is not a kind of state but a way of organizing a state as well as managing the society based on a democratic platform. In that sense, the rule of law is attached to and placed on a foundation of democracy. Democracy, therefore, is both the result and the condition of the state of law. The latter cannot exist under a non-democratic regime. That explains why in mankind's history, the idea of the rule of law emerged from ancient times, but not until the establishment of the capitalist state did it become a reality. As a way of managing the state on the foundation of democracy, the rule of law must be built and operated on the basis of democratic principles. According to WJP, those principles are:

- The government and its officials and agents as well as individuals and private entities are accountable under the law.

- The laws are clear, publicized, stable, and just; are applied evenly; and protect fundamental rights, including the security of persons and property.

- The process under which laws are enacted, administered, and enforced is accessible, fair, and efficient.

- Justice is delivered timely by competent court system. ${ }^{10}$

${ }^{8}$ Report of the Secretary-General on the Rule of Law and Transitional Justice in Conflict and Post-Conflict Societies (S/2004/616), http://www.unrol.org/files/2004\%20report.pdf.

${ }^{9}$ Madison (1788).

${ }^{10}$ http://worldjusticeproject.org/what-rule-law. 
Also, World Justice Project determines the criteria for evaluating the rule of law which include: ${ }^{11}$

- Limited Government Power: This criterion requires that powers and duties of the state bodies must be clearly defined in law and controlled by different checks and balances mechanisms in order to prevent the abuse of power including the organization of state power in accordance with the principle of separation of powers.

- Absence of Corruption: This criterion requires that the state does not accept and shall take all measures to combat corruption.

- Order and Security: This criterion requires the state to protect the rights, freedom, life and property of the citizens by means of prevention of all forms of crime and violence and lead the state under these dimensions: absence of crime, absence of civil conflict including terrorism, and armed conflict, and absence of violence as a socially acceptable means to redress personal grievances.

- Fundamental Rights: This criterion requires the state to respect, protect and ensure fundamental human rights embodied in the Universal Declaration of Human Rights.

- Open Government: This criterion requires the state to act on the principles of openness, transparency, accountability, promotion of contact, participation, cooperation and accessible possibility to the government of the people.

- Regulatory Enforcement: This criterion requires law must be strictly and timely enforced without unreasonable delay or improper interference. The government must pay compensation if damage is caused during the application of law.

- Civil Justice: This criterion requires the state to ensure that people have the ability to peacefully and effectively resolve conflicts, conflicts within the community (civil conflict) through formal judicial authorities but not some kind of self-administered justice by means of violence.

- Criminal Justice: This criterion requires the state to have an effective criminal justice system to prevent crime, ensure the order and security of society. This system must be independent from any external interference, but must ensure that human rights in criminal proceedings as well.

${ }^{11}$ http://worldjusticeproject.org/what-rule-law. 
- Informal Justice: This criterion requires the state to encourage the type of traditional justice (unofficially) as customary laws, local laws, reconciliation team to solve small conflicts within the community. However, unofficially justice must also comply with standards such as impartiality, efficiency and respect human rights.

\section{Understandings and Characteristics of the State of Law in Vietnam}

The idea of the rule of law was introduced to Vietnam in the early 20th century through revolutionaries and patriots like Phan Boi Chau, Phan Chu Trinh, Nguyen Ai Quoc. For instance, in his writings and speeches, Phan Chu Trinh heightens the role of a constitution and sees it as a legal instrument to limit the military monopoly and other abuses of power by the Eastern autocratic monarchies. He says

"Basing on the ideas of a person or a court to rule a country then that country is no more than a flock who are prosperous, happy or hungry all depending on the generosity of the shepherds. But a state built by the people means that people create by themselves constitution, laws, and institutions to serve the general concerns of people. "I2

For Nguyen Ai Quoc, the influence of Western ideas on the rule of law can be seen clearly in the document called "Claim of the people of Annam" (in French: Revendications du peuple annamite) which was sent to the Versailles Conference in 1919, the seventh demand of that document called for a replacement of the regime of arbitrary decrees by a regime of law. Following the success of the August Revolution, the Declaration of Independence of 1945 and the 1946 Constitution more clearly showed Ho Chi Minh's idea on the rule of law while confirming the natural equal rights of humans which set the foundation for the independence of the people (Declaration of Independence ) and helped to build a new Vietnam with a decentralized mechanism to control the power in a state characterized by the principle of the separation of powers, and a mechanism for the rights and obligations of citizens (1946 Constitution).

Since its foundation in 1930, the Communist Party of Vietnam has stressed the goal of building a democratic state under the doctrine of MarxismLeninism, i.e. a state led by the proletariat class (workers, peasants) to exercise

${ }^{12}$ Nguyễn Văn Dương (1995), 815-816. 
a dictatorship of the proletariat over the exploiting classes (bourgeoisie, landlords)to enforce basic human rights. For example, in the Brief Political Program published in 1930, the party defined its objectives:

- to overthrow the French imperialism and feudalism,

- to achieve full sovereignty of Vietnam,

- to build up a government controlled by workers, peasants and militants,

- to organize a workers and peasants army in order to ensure these aims,

- To realize goals like the freedom of association, equal rights of men and women, mass education, and reforms in industry and agriculture. ${ }^{13}$

The idea to build a proletariat state was then clearly pointed out in many party documents, especially in those of the $6^{\text {th }}$ National Party Congress (1976) stating that:

"the socialist state is the state of the proletariat, an organization performing the collective ownership of the working class and working people, an organization through which the party implements its leadership in the process of social development."

This idea was then embodied in the constitutions promulgated after 1946 with different levels and ways of expression, particularly in the 1980 constitution which states that: "The Socialist Republic of Vietnam is the state of proletariat" (article 2), "In the Socialist Republic of Vietnam the collective ownership is the working people including the working class, collective peasant class and socialist intelligentsia and other working people, among them the core alliance of workers and peasants is led by the working class" (article 3).

Since the $6^{\text {th }}$ Party Congress (1986), interpretation and viewpoints of the party on the proletariat state have been gradually changed. During the $6^{\text {th }}$ National Party Congress, although the term "proletariat state" was still used and confirmed that it is a model of a transitional state:

"Our state is the instrument of the socialist collective ownership in which the working class and working people organize organs of political power. In the transitional period, that is the proletariat state conducting the socialist democracy."

However, the interpretation of the function and mission of the proletariat state was renewed:

\footnotetext{
${ }^{13}$ Communist Party of Vietnam (1998), 2-3.

${ }^{14}$ National Political Publishing House (2000), 124.
} 
"Under the leadership of the party, the state function is institutionalized by law, rights, benefits and obligations of working people and economy and society are ruled by law. The state at the same time must ensure the really democratic rights of working people, and firmly punish those who violate the people's right. "'ls

In this case, the term "dictatorship" (to administer the state and society mainly based on guidelines, resolutions of the party) was eased and replaced by law. In addition, democratic rights were stressed more. This shows a positive movement toward the advance of the state of law approved by its superiority and rational elements in the world. The process was then promoted in the following party congresses. The $7^{\text {th }}$ National Party Congress stressed the importance of democratic practices by defining socialist democracy as the quintessence of the renewal process. The strengthening of the political system became both an objective and a motivation of Doi Moi. To innovate and strengthen the political system, the party advocates to continue promoting administrative reforms to reach the following aims: The state is of the people, by the people and for the people; the state put under the leadership of the party administers the society by law and is organized and operated according to the principle of democratic centralism; the state implements unified but decentralized power; the state structure is downsized and operated effectively. ${ }^{16}$

The state of law became politically fundamental for the national renovation process in the transitional period to socialism. Since then the Communist Party has continued to outline innovations for governance, for example in the $6^{\text {th }}$ and $7^{\text {th }}$ Party Congresses. They emphasized the role of the state in managing the society by law and created a general model for the organization of state power in Vietnam under which it is unified but assigned to three aspects: legislative, executive and judiciary. ${ }^{17}$

Expressing these ideas in such important documents demonstrates significant changes in the basic policy of the Communist Party when innovating the organization and operations of the state following the jurisdiction principle. This is considered premise for the Conference of the Central Party Committee (the $7^{\text {th }}$ Party Congress), the term "the state of law" was officially introduced

\footnotetext{
${ }^{15}$ National Political Publishing House (2000), 125.

${ }^{16}$ National Political Publishing House (2000), 297.

${ }^{17}$ National Political Publishing House (2000), 327.
} 
and views, principles and content of building the state of law was firstly defined in a more comprehensive way stating that the state of law of Vietnam is:

"The state of the people, by the people and for the people; the state administers all fields of the society by law and leads the country to a socialism-oriented development. The rule of law in Vietnam is built on the basis of strengthening and expanding its national unity, the alliance of working class and peasant class is seen as the core foundation and put under the leadership of the party. "18

Thus, the conference defined the very basic denotation of the term "the socialist rule of law in Vietnam". However, not until the $8^{\text {th }}$ Conference of the Central Party Committee in 1995 (the $7^{\text {th }}$ Party Congress) guidelines, solutions of innovation and perfection of the state toward a state of law were specified. In this conference, five central views on building the socialist state of law were identified:

- Building the socialist state of law of the people, by the people and for the people, the alliance of working, peasant class and intelligentsia is seen as the core foundation of Vietnam and put under the leadership of the Communist Party. The state fully implements the people's democratic rights, keeps the social order and exercises control over all acts violating the interests of the motherland and the people.

- State power is unified with the assignment and close coordination between state agencies in implementing the three powers: legislative, executive and judiciary.

- Putting into effect the principle of democratic centralism in the organization and operation of the Socialist Republic of Vietnam.

- Strengthening socialist legislation; building a state of law in Vietnam to control the society by law and improvements in education and socialist morality.

- Securing the leading role of the party in the Vietnamese State.

The above-mentioned views on building the socialist state of law were then confirmed and specified in the $8^{\text {th }}(1996), 9^{\text {th }}$ (2002) and $10^{\text {th }}(2006)$ National Congress of the Communist Party of Vietnam. Most recently, the $11^{\text {th }}$ National Congress of the Communist Party of Vietnam has stated:

"continue to promote and perfect socialist rule of law as well as ensure the state is really of the people, by the people and for the people and put under the leadership of

${ }^{18}$ National Political Publishing House (2000), 329. 
the party; the state implements effectively the economic and social management functions, at the same time properly resolves the relationship between the state and other institutions within its political system, with the people and with the market."

The congress also identified one of the most important instruments to build and perfect the socialist state of law:

"to research and to supplement specific institutional and mechanism operations to ensure the principle that all state power belongs to the people, and the principle of state power is unified with the assignment, coordination and control among agencies in the implementation of legislative, executive and judiciary; to enhance the role and effectiveness of economic management of the state in accordance with the requirements of economic development of the socialist-oriented market; to continue to improve the legal system, mechanisms and policies to effectively operate the economy and implement international commitments, protect national interests; to urgently study, modify the Constitution (1992) amended and supplemented in 2001 in order to be consistent with the new situation." 19

In order to meet the demand of the changes in the party's concept of the rule of law, article 2 of the Vietnamese Constitution, which was amended in the 2001, states: "The Socialist Republic of Vietnam is a socialist-law-governed state of the people, by the people and for the people. All state power belongs to the people; the foundation is the alliance of the working class with the peasantry and the intelligentsia. State power is unified with the assignment and coordination among agencies in the implementation of legislative, executive and judiciary". This is the first time the term "the rule of law" as well as the nature of the socialist state of law in Vietnam was officially confirmed in the Constitution of Vietnam.

The 2013 constitution continued to reaffirm that statement of the 1992 constitution, also in article 2, one important word was added i.e., "The Socialist Republic of Vietnam is a socialist-law-governed state of the people, by the people and for the people. The Socialist Republic of Vietnam is owned by the people; all state power belongs to the people; the foundation is the alliance of the working class with the peasantry and the intelligentsia. State power is unified with the assignment, coordination and control among agencies in the implementation of legislative, executive and judiciary." By adding the term "control", the 2013 constitution marked a huge step in accepting reasonable elements of state power control under the separation of powers model (alt-

${ }^{19}$ National Political Publishing House (2011), 246-247. 
hough this principle has not been accepted) that is commonly applied in many countries all over the world.

Based on the above ideas, it can be seen that since the foundation of the Communist Party of Vietnam, it has continually focused on building a model for a state and a law system which is compatible with the political goal of the party: to build a socialist government in Vietnam. The party's interpretation, awareness, and policies on this matter have gradually changed over the past years during which the biggest changes have been recorded since its launch of Doi Moi (1986). So far, the views of party and state on a socialist state ruled by law or a socialist legal state have been clearly shaped, whereby the socialist state rule of law includes the following basic characteristics: ${ }^{20}$

- The state is of the people, by the people, for the people; the people are the owner of the state.

- The state is organized and operated on the basis of the constitution; the state respects and protects the constitution.

- The state governs the society by law, and ensures the predominant position of law in social life.

- The state respects and protects human and civil rights.

- The state is organized on the basis of unified state power with the assignment, coordination and control among agencies in the implementation of legislative, executive and judiciary in accordance with the inspection and supervision of the implementation of state power through social organizations.

- The state is led by the only political party called the Communist Party of Vietnam.

These characteristics point out that the party's views and understandings of Vietnam have approached but not yet been completely updated with the common view on the rule of law of the international community. For instance, the first and the fourth characteristics are the most compatible meanwhile the fifth one only reaches the basic level of compatibility as according to the common agreement of the international community, one of the characteristics of a state of law is the principle of separation of powers which was not reflected in the $5^{\text {th }}$ characteristic.

${ }^{20}$ Nguyen Van Manh (2012), 17-21. 
Nevertheless, the biggest gap is shown in the last characteristic. If the socialist state of law in Vietnam is based on the leadership of one political party then a fundamental attribute of the rule of law, according to the common conception in the world is pluralistic politics in which political freedom i.e., freedom of association is guaranteed and civil society is protected and encouraged to be active.

\section{Advantages and Challenges in Promoting the Rule of Law}

The Vietnamese Constitution of 2013 creates fundamental advantages to promote the building of the state of law in Vietnam. In this constitution, one chapter and twenty seven articles were cut, only seven former articles remained, twelve articles were added, one hundred and one articles of the 1992 Constitution were amended; the 2013 Constitution contains many new provisions some of which are both direct and indirect prospects to promote the building of the state of law. However, in order to realize that vision it is required to overcome many challenges that can be generalized as follows.

The goal of building a socialist state ruled by law has been identified in the 2001 revision of the 1992 Constitution and embodied again in the 2013 Constitution pointed out in article 2 (The Socialist Republic of Vietnam is a socialist law-governed state of the people, by the people and for the people. State power is unified with the assignment, coordination and control among agencies in the implementation of the legislative, executive and judiciary); article 6 (Organizations and members that belong to the party operate within the framework of the constitution and law); article 8 (The state is organized and operated by constitution and law, society is governed also by constitution and law); articles 94, and 96 (The government implements the execute power and is responsible for protecting human rights and civil rights); article 102 (The people's court performs judicial authority and is responsible for the protection of justice as well as human rights); article 107 (The People's Procuration is responsible for protection of human rights and civil rights). These regulations are still general, however, they require amending the related laws, and thereby the organizational structure and operation of the state to be changed in a way that comes closer to the principles of the rule of law. 
However, to implement those above-stated innovations is not easy. As mentioned previously, the views, and perceptions of a socialist state of law in $\mathrm{Vi-}$ etnam are still not fully compatible with the common view of the world. There is still a difference between the conception of a socialist state of law with the common perception of the rule of law in two important points: organizational centralization of state power and political institutions. Therefore, the first and the most important challenge in promoting the rule of law in Vietnam is to deeply understand their nature and attributes.

More specific challenges relate to the implementation of the assignment, coordination and control between the legislature, executive and judiciary in the context that state power in Vietnam is considered to be unified and centralized in the National Assembly as well as ensured by a Communist Party of Vietnam which is on the one hand the sole head of state and society, and on the other hand is answerable to the people and subject to the supervision of the people (article 4 of 2013 constitution). These are also the issues that contain theoretically unclear, even contradictory factors, and in fact, they have not ever been implemented and regulated in our law system.

By reaffirming and clarifying the people's sovereignty (mentioned in the constitutions of 1959, 1980, 1992), the 2013 Constitution also creates great opportunities for the expansion of democracy - the basis of the rule of law in a number of regulations: It is stated in the preamble (people are the actors who build, implement and protect the constitution); in article 2 (people are the owners of the country, all state power belongs to the people); in article 4 (the party, party organizations and party members are subject to the supervision of the people and responsible for their decisions); in article 6 (the way the people implement state power is direct and representative democracy); in article 70 ("The National Assembly is the only organ with constitutional power" no longer exists); in article 120 (regulates a referendum on the constitution). These new amendments together with the capitalized term "People" indicate that the role of people's power is solemnly acknowledged in the 2013 Constitution. They also show the shift in the main features of the state to the idea that the state is a social contract in which people are establishing subjects; people empower and work out mechanisms to control the operation of the government created by them. These changes promise to promote the expansion of democracy in our country in the coming years. 
However, the expansion of democracy may encounter many challenges. Currently, in Vietnam, there is still no clear legal framework and effective implementation of democratic rights, in particular the absence of a series of legal foundations for a democratic society, including the law on political parties, the law on association, protest law, law on referendum, and the law on access to information. The legal framework of a representative democracy (the law on election of deputies to the National Assembly and the law on election of deputies to the People's Council) exists but contains many obsolete provisions and needs to be modified to be compatible with the new situation (e.g., regulations on candidates, nomination, negotiation of candidates). Although direct democracy was firstl introduced and emphasized in the 2013 Constitution, there is still not any specific law and the concept itself has not really been clarified in our country.

The 2013 Constitution also creates opportunities for a state governance reform which is indeed related directly to the building of the state of law. Series of newly added or amended regulations express the efforts of law -makers in forming a new framework for the governance of the country e.g., article 2 (control function among agencies in the implementation of the legislative, executive and judiciary); article 55 and 112 (decentralization between central and local level under a development model allowing local government to have its own budget); article 117 and 118 (two independent constitutional authorities are established: the National Election Council and the State Audit); article 9 (the role of criticism and supervision of the Vietnam Fatherland Front and its members is clarified). These new revisions promise to promote reforms toward building transparent governance, efficiency and accountability and meet the demands arising from the process of democratization, and international integration of Vietnam.

Despite that, there are also challenges in the reformation of national governance. Only criticism and monitoring issues of the Vietnam Fatherland Front and its members have been regulated, ${ }^{21}$ other significant issues that reflect a framework of national governance reform added in the 2013 Constitution i.e., a mechanism of mutual control between the legislature, executive and judiciary; separation of powers between the central and local level according to a development model; organization and operation of two independent constitu-

${ }^{21}$ See Politburo of the Communist Party of Vietnam (2013). 
tional bodies as the National Election Council and State Audit have not yet been specified in our country, as this requires the new promulgation and revision of many related laws.

However, the biggest difficulty is not the legislative issue, because Vietnamese law makers and legal experts are qualified to build a legal framework for transparent governance, efficiency and accountability, but the obstacles to the establishment and operation of institutional control and power monitoring. This is expressed in the regulation of the Constitutional Council - an independent constitutional institution, upon which almost all Vietnamese legal experts agree, the role of which is as a strong agency to control power; however, it was removed from the 2013 Draft Constitution (amended version). Another example is the building of the Law on Criticism and Supervision of the Vietnam Fatherland Front and its member organizations (to codify the Regulation on supervision and social criticism of the Vietnam Fatherland Front, mass organizations of the Politburo) has been delayed, despite of the fact that it has long been proposed by the Front itself. In short, the novelty and complexity of institutional controls, power supervision along with their potential conflicts with the closed mode of operation of the current state institutions show that the reform of the framework of governance under the 2013 Constitution of our country will not be easily and quickly completed.

The 2013 Constitution creates an unprecedented opportunity to complete the constitutional framework of human, and civil rights - one of the factors and basic foundation of the rule of law. Human rights institutions and citizen rights are mostly amended and supplemented in the 2013 Constitution. The amendments and supplements represent a new approach closely associated with common human recognition as well as the standards of international law on human rights. That is shown as follows.

In the former 1992 Constitution, chapter 5 called "Rights and responsibilities of the citizen" is now changed to chapter 2 and renamed "Human rights, rights and responsibilities of citizen". The former term "Rights and responsibilities of citizen" does not completely encompass the content of the chapter, this change also confirms the important role of this institution within the constitution, at the same time being with compatible general trends in the world.

Human and citizens' rights are no longer seen equally (as shown in the 1992 Constitution) but these two terms are used for institutional rights, e.g., 
equality before the law; business freedom; private ownership of property and productive assets; rights in scientific research and technology, literary and artistic creation and to receive the benefits from such activities; the right to the protection, and health care; freedom of belief and religion; the right to inviolability of the body, health, honor and dignity protected by law are stipulated in the 1992 Constitution only for citizens. However, the 2013 Constitution stipulates that this applies to everyone. Therefore, not only Vietnamese citizens but foreigners living in Vietnamese territory are also protected.

Three obligations of the state are acknowledged in accordance with international human right law: respect, protect and guarantee human rights (in article 3 and 14 of the 2013 constitution meanwhile, the obligation to respect was only referred to in article 50 of the 1992 Constitution). This change not only ensures the harmonization with international human rights law, but also forms the institutional basis that binds constitutional agencies to fully and seriously implement the obligation in human rights, citizen rights in reality, especially the dual obligation of protection and guarantee.

The principle of limited power is defined for the first time (paragraph 2, article 16) which has been outlined in international human rights law and in the constitution of a number of countries. The constitutional principles have important implications, because: This clarifies the spirit of international human rights law, that means the state must respect, protect and guarantee human rights but also set and apply the limits for a number of rights in order to perform the functions of the state's social management, ensure the rights and interests of the community and the rights and legitimate interests of other individuals. It prevents the potential abuse of state power to violate human rights; this is done through the stipulation of strict conditions for the limitation of rights. It prevents inordinateness in the extreme uses and actions in the enjoyment of rights.

Adding some new rights which have not been addressed in the 1992 and previous Constitutions of Vietnam that include: right to life (article 21); cultural rights (article 41); the right to determine ethnicity, native language, choose the language of communication (article 42); right to live in a healthy environment (article 43); citizens cannot be deported and handed over to other states (article 17 paragraph 2); the right to have legal residence (article 22); the right to social security (article 34). These new rights expand the scope of constitutional protection for human rights, citizen rights in both civil and politi- 
cal fields (article 21, 17, 42) as well as in economic, social, cultural fields (Article $41,42,43,22,34)$ and meet the new demands on human rights emerging in the context of industrialization, modernization and international integration of our country.

Most of the recognized articles in the 1992 Constitution are strengthened (specified or detailed in separate articles):

- equality before the law (article 16),

- prohibition of torture, violence, coercion, and corporal punishment (article 20 paragraph 1 ),

- privacy and residence (articles 21 and 22),

- access to information (article 25),

- participation in state governance and social affairs (article 28),

- gender equality (article 26),

- voting in a referendum (article 29),

- procedural fairness (article 31),

- private property (article 32),

- labor and employment (article 35).

The revised rules also contribute to enhancing the level of compatibility of the rule of human rights, civil rights in the 2013 Constitution which is compatible with the contents of international treaties on human rights to which $\mathrm{Vi}$ etnam is a member and with provisions on human and civil rights in the constitutions of democratic countries.

However, there are still many challenges in the assurance of human and constitutional rights of citizens in the 2013 Constitution. The first obstacle is that the 2013 Constitution does not regulate the direct effect of constitutional rights. This means that many important rights, especially civil and political rights as freedom of association, meeting, demonstration, the right to vote in the referendum will have to wait for the National Assembly to enact laws and for the government to issue decrees to guide the implementation.

The second obstacle is that there is still no clear legal and effective mechanism for the protection of constitutional rights. As the Constitutional Council has not yet been established, there is no possibility to prevent and effectively deal with the documents and decisions that violate the constitutional rights (unconstitutional) of the legislature, executive and judiciary. Similarly, the proposal of a national human rights agency is ignored causing the elimination of people's opportunity to be protected by an independent constitutional agen- 
cy. Currently, through the mechanism for resolving complaints and denunciations designed as "to be a judge of one's own case" (complaints and denunciations are solved by the authorities which themselves create the complaints and denunciations in the first place or by their higher authorities) and through the judicial system that is lacking in independence, the ability to solve and compensate properly the violation of human rights, citizen rights, especially civil rights, and politically sensitive rights is limited.

The third major obstacle relates to unreasonable regulations applied to issues of national security in order to restrict rights (article 14) including the broad and vague prohibition of the abuse of human and citizen rights to violate national interests, legitimate rights and interests of others (article 15). In fact, these rules have been misused to violate constitutional rights. In the context of the judicial system which is not acting in the defense of justice together with the lack of an independent institution in human rights protection namely the Constitutional Council and a national human rights body, the ability to stop the abuses described above will be very difficult.

\section{References}

ABA: What is rule of law, http://www.americanbar.org/content/dam/aba/migrated/publiced/features/Part1DialogueROL.authcheckdam.pdf.

Communist Party of Vietnam (ed.) (1998): Party Documents. Complete Collection. Hanoi.

http://worldjusticeproject.org/what-rule-law.

http://www.oxforddictionaries.com/definition/english/rule $\% 2 \mathrm{Bof} \% 2 \mathrm{Blaw}$

$1 ? \mathrm{q}=$ rule + of + law

Madison, James (1989): The Structure of the Government Must Furnish the

Proper Checks and Balances Between the Different Departments (Federalist

Paper No. 51, 1788): In: Hamilton, Alexander/Madison, James/Jay, John: The Federalist Papers. New York.

Magna Carta, article 39 , at: http://www.historylearningsite.co.uk/magna_carta-transcript.htm.

National Political Publishing House (ed.) (2000): Documents of Party Congresses in Doi Moi period (the $6^{\text {th }}, 7^{\text {th }}, 8^{\text {th }}$ and $9^{\text {th }}$ Congresses). Hanoi. 
National Political Publishing House (ed.) (2011): Documents of $9^{\text {th }}$ Party Congress. Hanoi.

Nguyễn Văn Dương (ed.) (1995): Selected Works of Phan Chu Trinh. Da Nang. 815-816. Cited according to Phan Đăng Thanh, Constitutional Thought of Phan Chu Trinh, at: http://www.na.gov.vn/Sach_QH/Ban\%20ve\%20lap\%20hien/Chuong1/5.htm.

Nguyen Van Manh (2012): Building the Socialist Rule of Law-Based State of the People, by the People, for the People. Hanoi.

Politburo of the Communist Party of Vietnam (2013): Regulation on Supervision and Social Criticism of the Vietnam Fatherland Front, Mass Organizations Issued together with Decision 217-QD/TW, December 12, 2013 of the Politburo of the Communist Party of Vietnam. Hanoi.

Quotes.liberty-tree.ca/quote_blog/Marcus.Tullius.Cicero.Quote.7330.

Report of the Secretary-General on the Rule of Law and Transitional Justice in Conflict and Post-Conflict Societies (S/2004/616), http://www.unrol.org/files/2004\%20report.pdf.

Stephens, James (1985): Socrates on the Rule of Law. In: History of Philosophy Quarterly. Vol. 2, No. 1. 3-10. www.quotationspage.com/quote/28897.htm. 